INFORMASI: Kajian Ilmu Komunikasi - ISSN (p) o126-o650; ISSN (e) 2502-3837

Vol. 48, No. 1 (2018), pp.49-63. doi: http://dx.doi.org/10.21831/informasi.v48i1.17799

\title{
STRUKTURASI KOMUNIKASI INTERNAL DALAM PRAKTIK MEDIA RELATIONS DI DALAM INDUSTRI MEDIA
}

\author{
Brahma Putra Pratama \\ brahma_putra@staff.uajy.ac.id \\ Program Studi Ilmu Komunikasi, Fakultas Ilmu Sosial dan Ilmu Politik \\ Universitas Atma Jaya Yogyakarta
}

\begin{abstract}
Media relations is one of the practices that can be found in the system of a public relations (PR) department. The PR department of a media industry still needs to do the practice of media relations with other media industry although it has already had its own channel to disseminate information. The practice of media relations has aim that the information from an organization can be distributed to the public through the channel of the media industry. To achieve the aim, the initial process, such as the interaction and communication in the internal environment of the organization between the PR staff with the superiors, is required. PR staff and the superiors as the agents use the structure to act in the process of system production and reproduction. To know how the process of the system production and reproduction in the interaction of the agents in the practice of media relations, then analysis using adaptive structuration theory developed by McPhee and Poole is required. This research aims to describe and provide an understanding of structuration of internal communication in the practice of media relations in the PR department. The method used in this research is a single instrumental case study with descriptive qualitative approach. From this study, it is found that in the $P R$ department system, the staff connects to the superiors in the internal environment in the practice of media relations and the agents use the structure to act and to interact so that the system and practice can take place continuously either as a rountine or as a transformation.
\end{abstract}

\begin{abstract}
Abstrak
Media relations merupakan salah satu praktik yang terdapat dalam sistem departemen public relations (PR). Departemen PR dari suatu industri media ternyata masih perlu melakukan praktik media relations dengan industri media lain meskipun telah memiliki saluran media untuk menyebarkan informasi. Praktik media relations bertujuan supaya informasi dari suatu organisasi dapat disebarluaskan kepada publik melalui saluran suatu industri media. Untuk mencapai tujuan tersebut, diperlukan proses awal berupa interaksi dan komunikasi di lingkungan internal organisasi antara staf PR dengan atasannya. Staf PR dan atasannya sebagai agen menggunakan struktur dalam bertindak dalam proses produksi dan reproduksi sistem. Untuk mengetahui bagaimana proses produksi dan reproduksi sistem tersebut dalam interaksi para agen dalam praktik
\end{abstract}


media relations, maka diperlukan analisis menggunakan teori strukturasi adaptifyang dikembangkan oleh McPhee dan Poole. Penelitian ini bertujuan untuk menggambarkan dan memberikan pemahaman mengenai strukturasi komunikasi internal dalam praktik media relations yang terjadi di dalam departemen PR. Metode yang digunakan dalam penelitian ini adalah studi kasus instrumental tunggal dengan pendekatan kualitatif deskriptif. Dari penelitian ini ditemukan bahwa di dalam sistem departemen PR, staf berhubungan dengan atasannya di lingkungan internalnya dalam melakukan praktik media relations dan para agen menggunakan struktur dalam bertindak dan berinteraksi sehingga sistem dan praktik dapat berlangsung terus-menerus baik sebagai rutinitas maupun sebagai transformasi.

Keywords: Structuration, Internal Communication, Media Relations, Media Industry.

\section{PENDAHULUAN}

Public Relations (PR) merupakan bagian yang penting dalam organisasi yang berkaitan dengan komunikasi antara organisasi dengan publiknya. Salah satu strategi komunikasi yang digunakan oleh seorang PR adalah media relations. Dengan strategi media relations, PR dapat memperoleh publikasi yang menjangkau khalayak luas dan membangun serta mempertahankan reputasi. Di dalam media relations, PR melakukan interaksi dengan redaksi media, terutama dengan jurnalis yang meliput dan menulis berita tentang organisasi di mana PR bekerja. Hubungan yang terjalin antara PR dan jurnalis menjadi penentu dalam pemberitaan yang ditulis oleh jurnalis. Akan tetapi, hubungan yang terjalin tersebut tidak selalu berjalan dengan baik dan lancar karena ada kesalahpahaman atau komunikasi yang tidak terjalin dengan baik. Pang (2010, hlm. 194) menyebutkan bahwa kesalahpahaman dapat muncul karena praktisi PR tidak memahami apa yang jurnalis inginkan, seperti apa perkerjaan jurnalis, dan bagaimana media relations yang tepat.

Hubungan dengan media sebagai publik perlu dilakukan karena dengan khalayak yang tersebar, bukan saja secara geografis tetapi juga secara demografis, maka kegiatan komunikasi akan sulit dilakukan jika tidak memanfaatkan media massa (Iriantara, 2005, hlm. 10). Dalam media relations, terdapat berbagai macam aktivitas yang dilakukan PR untuk menjalin relasi dengan jurnalis. Theaker menyebutkan bahwa ada beberapa aktivitas untuk melakukan kontak dengan jurnalis, seperti press conference, media briefing, exclusive interviews, feature articles dan photo opportunities (2004, hlm. 149). Untuk mendapatkan publikasi yang mendukung produk dan layanan dari organisasi, PR biasanya memberikan information subsidy atau informasi yang tersedia bagi media berita untuk meningkatkan reputasi organisasi (Pang, 2010, hlm. 192). Aktivitas-aktivitas media relations tersebut dapat dijalankan jika sebelumnya terdapat interaksi dan komunikasi antara karyawan yang terjadi di dalam lingkungan internal organisasi. Dengan kata lain, untuk melakukan aktivitas media relations sebagai sebuah komunikasi ekternal, maka diperlukan komunikasi internal atau komunikasi di dalam organisasi antara staf media relations dengan staf yang lain atau dengan atasannya. Zelko dan Dance dalam Goldhaber (1993, hlm. 12) mengungkapkan bahwa komunikasi organisasi adalah sistem yang interdependent (saling tergantung satu sama lain) serta meliputi komunikasi internal (upward, downward, dan horizontal).

Peran PR pada saat ini hampir dapat ditemui di berbagai macam industri dan organisasi, salah satunya adalah industri media. PR dalam industri media menjadi hal yang unik karena tempat di mana PR tersebut bekerja sudah memiliki saluran yang dapat mempublikasikan informasi terkait industrinya. Akan tetapi, saluran 
yang dimiliki oleh perusahaan media tersebut dirasa tidak akan menjangkau khalayak yang lebih luas, oleh karena itu, PR industri media melakukan media relations dengan perusahaan media yang lain. Di Indonesia, pada umumnya, praktik media relations antar industri media tidak terjadi dalam sektor yang sama. Dengan kata lain, sebuah industri media televisi tidak akan menjalin hubungan dengan industri media televisi lain, tetapi menjalin relasi dengan industri media online atau media cetak. Hal ini disebabkan adanya persaingan antar industri media dalam kebaharuan informasi sebagai sumber daya yang menentukan kelangsungan operasional industri media tersebut.

Salah satu media yang menjalankan praktik media relations adalah Trans TV. Trans TV merupakan salah satu industri media televisi yang menggunakan kreativitas sebagai sumber dayanya untuk menjaga kelangsungan hidup industri. Trans TV menyadari bahwa jangkauan Trans TV terbatas sebagian besar jumlah penduduk Indonesia dengan berbagai kepentingan dan persebarannya yang luas sehingga menjalin hubungan dengan media-media lain di Indonesia diperlukan demi memperluas dan mempercepat penyebaran informasi. Praktik media relations di Trans TV dapat ditemukan di dalam Departemen Marketing Public Relations (PR). Untuk memahami berlangsungnya praktik media relations melalui interaksi-interaksi staf media relations dengan karyawan lain, baik antar staf maupun dengan atasan, dibutuhkan pendekatan melalui konsep-konsep yang terdapat dalam teori strukturasi yang dikemukakan oleh Anthony Giddens. Teori strukturasi merupakan teori yang mendiskusikan tentang transformasi struktur dan reproduksi sistem. McPhee dan Poole (2005, hlm. 180) menyatakan bahwa teori strukturasi menjelaskan bagaimana sistem sosial seperti organisasi diproduksi dan direproduksi melalui proses strukturasi yang sedang berlangsung. Akan tetapi, teori strukturasi merupakan sebuah teori yang besar dengan konteks atau pada level masyarakat, sehingga untuk membawa ke dalam level yang lebih kecil (organisasi dan kelompok) diperlukan sebuah teori yaitu adaptive structuration theory yang dikembangkan oleh Poole dan McPhee.

Kelompok kecil memainkan peran penting dalam masyarakat sebagai salah satu konteks nyata di mana individu dapat memahami struktur dalam level masyarakat (yaitu, norma berbicara, pola kekuasaan, aturan linguistik) dan mempertahankan atau menghilangkannya (Littlejohn \& Foss, 2009, hlm. 458). Dalam konteks organisasi, para anggota sebuah departemen public relations (PR) dapat memiliki pemahaman mereka sendiri bagaimana peran departemen mereka dapat memproduksi dan mereproduksi kehidupan masyarakat yang sedang berlangsung melalui struktur dan interaksi mereka dengan publik. Menurut Poole, kelompok yang sukses terkadang perlu mengubah aturan-aturan yang mereka gunakan untuk menyelesaikan masalah dan membuat keputusan (Littlejohn and Foss, 2009: 863). Dengan kata lain, jika ada transformasididalam Departemen Marketing PR Trans TV, maka akan membantu para anggota departemen berkomunikasi ketika menghadapi krisis, menjalin relasi baik internal maupun eksternal serta ketika membuat keputusan.

Dengan menganalisis strukturasi dari Departemen Marketing Public Relations (PR) Trans TV sebagai sebuah sistem, maka dapat dijelaskan cara-cara bagaimana sistem diproduksi dan direproduksi dalam interaksi para agen dalam lingkungan internal. Oleh karena itu, dari uraian tersebut, maka dapat dirumuskan pertanyaan: Bagaimana strukturasi komunikasi internal dalam praktik media relations yang dilakukan oleh departemen marketing public relations (PR) suatu industri media?

Penelitian ini berusaha menggambarkan dan memberikan pemahaman interpretif mengenai proses dinamika dalam komunikasi internal yang terjadi dalam praktik media relations di dalam lingkungan internal industri media di mana departemen marketing public relations (PR) beroperasi. 
Karenanya, tujuan penelitian ini adalah untuk menggambarkan dan memberikan pemahaman mengenai strukturasi komunikasi internal dalam praktik media relations yang terjadi di dalam departemen marketing PR.

\section{KAJIAN PUSTAKA}

\section{Adaptive Structuration Theory}

Teori strukturasi merupakan sebuah teori yang besar dan berada dalam konteks masyarakat sehingga untuk membawanya ke level yang lebih kecil (level organisasi dan kelompok) diperlukan sebuah teori untuk menyesuaikannya ke konteks yang dituju. Teori strukturasi dapat dikatakan sebagai teori yang besar karena melibatkan serangkaian konsep dan model teoritis. Untuk membawa teori strukturasi ke dalam konteks organisasi atau kelompok, Poole dan McPhee serta rekan-rekan mengemukakan adaptive structuration theory (AST). Poole menyebut adaptive structuration theory karena dia mengamati para anggota kelompok kerja yang mengadaptasi aturan dan sumber daya untuk mencapai tujuan mereka (Griffin, 2006, hlm. 238). Mc Phee dan Poole menyebutkan bahwa konsep kunci dalam adaptive structuration theory (AST) adalah appropriation, yaitu cara di mana kelompok menggunakan aspek struktural (aturan atau sumber daya), seperti aspek voting dalam group support system (GSS) dan menggunakannya dalam interaksi (2005, hlm. 183).

Teori strukturasi menekankan pada institusi sosial sebagai dasar untuk menjelaskan masyarakat dan komunikasi karena teori ini berusaha menjangkau keberlangsungan dari interaksi mikro hingga institusi makro berdasarkan pengaruh agen-agen dan kecenderungan struktural. Strukturasi melibatkan teori komunikasi dan organisasi berdasarkan proses yang menjelaskan bagaimana sistem sosial, termasuk organisasi, diproduksi dan direproduksi melalui penggunaan struktur. Sistem dalam teori strukturasi adalah produk dari tindakan manusia yang terjadi melalui dualitas yaitu struktur sebagai medium dan outcome tindakan. Strukturasi terjadi karena adanya tindakan manusia dan struktur sosial di dalam interaksi.

\section{Strukturasi dalam Organisasi}

Teori strukturasi mencangkup struktur sosial (social structure) dan tindakan manusia (human interaction) sehingga kerangka teori strukturasi dapat menjelaskan perilaku individu dan perkembangan dan efek institusi sosial. Teori ini berguna bagi komunikasi karena berfokus pada interaksi sebagai arena di mana proses strukturasi terjadi dan berguna untuk memahami komunikasi sebagai sebuah proses (McPhee \& Poole, 2005, hlm. 180). Teori strukturasi menjelaskan bagaimana sistem sosial seperti organisasi diproduksi dan direproduksi melalui proses strukturasi yang sedang berlangsung di mana ada produksi, reproduksi, dan transformasi institusi sosial yang diwujudkan melalui pengunaan aturan oleh individu-individu (Yates \& Orlikowski, 1992, hlm. 188).

Dualitas strukturasi dapat tercemin ketika aturan-aturan membentuk tindakan oleh individu-individu dalam organisasi dan pada saat yang bersamaan, individuindividu tersebut menggunakan aturan untuk memodifikasi institusi sosial dalam interaksi yang sedang berlangsung. Konsepkonsep utama dalam teori strukturasi menurut McPhee dan Poole (2005, hlm. 174180) meliputi: (1) sistem/praktik/struktur, (2) dualitas struktur: produksi dan reproduksi, dan (3) agensi.

Sistem dalam teori strukturasi adalah sistem dari praktik manusia (human practice). McPhee dan Poole (2005, hlm. 174) mengartikan sistem sebagai pola hubungan dalam praktik yang dapat diamati dan pola tersebut juga meliputi hubungan antara operasi-operasi dan divisidivisi. Praktik tersebut (1) merupakan pola aktivitas yang bermakna bagi mereka yang terlibat di dalamnya, (2) mengatur aktivitas manusia terkait dengan manusia yang lain dan dapat memunculkan serangkaian 
tindakan serta memiliki kriteria akhir dalam rangkaian tindakan tersebut, (3) melibatkan improvisasi karena selalu ada perbedaan dalam implementasi, tergantung pada konteksnya, dan (4) bisa melalui hal yang kecil maupun dalam hal yang besar. Struktur menurut Weick merupakan suatu aktivitas komunikasi yang ditentukan oleh perilaku para anggota organisasi yang saling bertautan (Fadillah, 2017, hlm.123). Akan tetapi, struktur dalam teori strukturasi adalah aturan-aturan (rules) dan sumber daya (resources) yang dibawa oleh aktoraktor yang terlibat dalam praktik sistem (McPhee \& Poole, 2005, hlm. 174). Sebuah aturan (rule) adalah prinsip atau rutinitas yang memandu orang dalam bertindak dan sebuah sumber daya (resource) adalah segala sesuatu yang orang gunakan dalam bertindak, baik itu materi (uang, peralatan) maupun nonmateri (pengetahuan, skill).

Inti dari teori strukturasi, yaitu dualitas struktur. Dualitas struktur adalah setiap tindakandansetiapepisodeinteraksimemiliki dua aspek: tindakan "memproduksi" praktik dan "mereproduksi" sistem dan struktur sistem, serta biasanya terjuwud dalam hal yang kecil baik dengan perubahan atau tidak (McPhee \& Poole, 2005, hlm. 175). Dengan kata lain, sistem itu sendiri merupakan produk dari tindakan manusia yang terwujud dalam dualitas strukturyaitu sebagai medium dan sebagai hasil tindakan. McPhee dan Poole (2005, hlm. 175) menjelaskan bahwa ketika kita membawa aturan dan sumber daya untuk bertindak dalam sebuah sistem praktik sosial, kita menjaga sistem tersebut tetap berjalan atau dengan kata lain kita memproduksi kembali (reproduce) sistem dan strukturnya. Produksi dapat berupa tindakan transformasi, yaitu produksi sistem ke arah yang berbeda sehingga dengan perubahan tersebut reproduksi sistem tetap dapat berlangsung (McPhee \& Poole, 2005, hlm. 175).

Agen mengacu pada individu-individu yang melakukan produksi dan reproduksi sistem dan struktur sistem. Sedangkan agensi mengacu pada tindakan atau kemampuan manusia ketika melakukan sesuatu sehingga individu-individu dapat bertindak secara berbeda dalam setiap fase apa pun dalam suatu urutan tindakan tertentu (Giddens, 2010, hlm. 14).

\section{Komunikasi Internal}

Komunikasi internal mengacu pada komunikasi yang terjadi dalam lingkungan organisasi. Komunikasi internal terjadi ketika anggota sebuah organisasi saling berinteraksi. Untuk memahami interaksi pihak-pihak yang terlibat dalam pelaksanaan aktivitas media relations maka diperlukan penelusuran pola jaringan komunikasi yang terbentuk di antara mereka. Melalui penelusuran pola jaringan komunikasi, maka dapat diperoleh gambaran tentang bagaimana pesan mengalir, melalui saluran apa pesan tersebut disampaikan, dan siapa yang memengaruhi siapa dalam interaksi. Inilah menyebabkan jaringan komunikasi menjadi dinamis karena jaringan yang ditentukan oleh interaksi dapat mudah sekali berubah (Papa, Daniels, \& Spiker, 2008, hlm. 51). Jaringan mengacu pada kesepakatan bersama atau aturan siapa yang boleh berbicara dengan siapa dan links mana yang berguna atau berharga. Jaringan komunikasi internal dalam organisasi secara struktural terjadi dalam jaringan komunikasi formal. Papa et al. mendefinisikan jaringan komunikasi formal sebagai komunikasi yang dilakukan melalui saluran aliran pesan formal yang didesain antara posisi-posisi dalam organisasi (2008, hlm. 51). Posisiposisi ini mengacu pada konsep hirarki yang mendasar dalam kehidupan organisasi.

Dalam komunikasi internal, Papa et al. menguraikan empataliran pesan berdasarkan sistem hirarki, yaitu downward (dari atas ke bawah), upward (dari bawah ke atas), horizontal (antar posisi yang sejajar (peer) dalam satu departemen), dan diagonal (antar departemen) (2008, hlm. 61). Komunikasi downward merupakan komunikasi yang terjadi dari atasan kepada bawahannya. Goldhaber menyatakan bahwa komunikasi downward merupakan komunikasi atasan ke bawahan, pesan-pesan mengenai tugas 
dan pemeliharaan terkait dengan arahan, tujuan, disiplin, perintah, pertanyaan dan kebijakan (1993, hlm. 155). Komunikasi upward merupakan komunikasi yang terjadi dari bawahan ke atasan. Komunikasi upward melibatkan transmisi pesan dari tingkat yang lebih bawah ke tingkat yang lebih tinggi dalam organisasi (Papa et al., 2008, hlm. 53). Komunikasi upward ini dapat berguna dalam pembuatan keputusan (decision-making), pemecahan masalah (problem solving) dan pengembangan kebijakan dan prosedur. Komunikasi horisontal terjadi di antara anggota organisasi dari divisi/departemen/ unit/sub-unit yang berbeda dengan posisi hirarki yang setara dalam suatu organisasi. Komunikasi horisontal mengacu pada aliran pesan yang terjadi antar area fungsional pada level tertentu dalam organisasi (Papa et al., 2008, hlm. 55). Dalam komunikasi horisontal terdapat fleksibilitas yang memudahkan untuk melakukan koordinasi tugas, penyelesaian masalah, penyebaran informasi, dan resolusi konflik (Papa et al., 2008, hlm. 56). Komunikasi diagonal merupakan komunikasi yang terjadi antar tingkat kedudukan dan fungsi atau departemen dalam organisasi (Papa, et al., 2008, hlm. 57). Konteks komunikasi diagonal merupakan komunikasi yang melibatkan lingkungan internal dan eksternal sistem. Arah komunikasi mempunyai peran sebagai landasan kerja yang memungkinkan komunikasi dapat berjalan di dalam suatu organisasi (Fadillah, 2017, hlm.123)

\section{Media Relations}

Media relations merupakan praktik yang melibatkan komunikasi internal dan komunikasi eksternal. Dalam komunikasi internal, media relations melibatkan interaksi antara karyawan dalam organisasi, khususnya departemen public relations. Sedangkan komunikasi eksternal adalah tentang relasi kerja antara PR dan media (jurnalis). Menurut Theaker, media relations terdiri atas mekanisme melakukan kontak dengan media, penulisan press release dengan format yang spesifik supaya memenuhi kebutuhan jurnalis, dan cara terbaik dalam menarget dan mendistribusikan informasi (2004, hlm. 149). Menurut Johnston (2013, hlm. 1), media relations adalah tentang membangun hubungan profesional, mengetahui bagaimana media berita beroperasi, memahami timeframes, deadline, format dan praktek dari media, dan menggunakan media sebagai barometer bagi masyarakat. Media relations tidak hanya terkait dengan kepentingan sepihak, organisasi atau media massa saja, melainkan kedua pihak memiliki kepentingan yang sama. Dengan demikian akan membuat hubungan kerjasama menjadi hubungan yang sama-sama menguntungkan bagi kedua belah pihak (Andjani, 2009, hlm. 62).

Selain itu, mempertahankan hubungan yang berlangsung untuk jangka yang panjang merupakan hal yang sangat penting dalam media relations. Perusahaan perlu mengembangkan hubungan jangka panjang (long-term relationship) dengan jurnalis yang tepat untuk industri mereka (Argenti, 2003, hlm. 111). Theaker menyebutkan bahwa ada berbagai metode untuk melakukan kontak dengan jurnalis, seperti press conference, media briefing, exclusive interviews, feature articles dan photo opportunities (2004, hlm. 149).

\section{Industri Media}

Industri media adalah media massa yang dipandang sebagai institusi ekonomi. Menurut Picard dalam Albarran (2002, hlm. 3), media adalah insitusi ekonomi yang terlibat dalam produksi dan penyebaran konten yang ditujuan kepada konsumen. Industri media dapat dikatakan sebagai 'creative industries' jika menggunakan strategi advertising, marketing, dan public relations (Küng, 2008, hlm. 7). Dari perspektif ekonomi, kreativitas adalah resource strategis yang sangat penting bagi media karena merupakan nature dari budaya (Küng, 2008, hlm. 145). Nilai media products berasal dari pengetahuan dan kreativitas pembuat konten. Küng menyebutkan bahwa jika semakin tinggi tingkat kebaruan (novelty) dan kreativitas, maka semakin besar 
potensi keuntungan (2008, hlm. 9). Hal ini menjadikan keunggulan kreativitas sebagai sumber daya organisasai (organizational resources). Oleh karena itu, sebagai institusi ekonomi, media tidak terlepas dari resource (sumber daya).

\section{METODE}

Paradigma yang digunakan dalam penelitian ini adalah paradigma interpretif. Putnam (1983, hlm. 31) menyatakan bahwa paradigma interpretif sebagai interpretasi manusiadalammencaricarauntukmemaknai dunianya melalui perilaku komunikasi dan interpretasi tersebut berdasarkan pada sumber (source), sifat alami (nature), dan metode untuk menginvestigasi kehidupan organisasi. Paradigma interpretif digunakan untuk memahami dinamika interaksi yang terjadi antara staf Public Relations dan atasannya melalui tindakan-tindakan mereka. Pendekatan penelitian yang digunakan oleh peneliti adalah kualitatif untuk menjelaskan fenomena dalam praktik media relations yang terjadi terkait interaksi yang terjalin di antara para agen, khususnya staf media relations dengan para pihak manajerial PR. Denzin dan Lincoln (1994, hlm. 4) menjelaskan bahwa penelitian kualitatif menekankan pada proses dan maknayang tidak diuji atau diukur melainkan untuk menjelaskan fenomena yang diteliti. Fenomena dalam riset ini adalah interaksi para agen yang terjadi dalam praktik media relations ditinjau dari aturan atau prosedur yang ada. Pola berpikir grounded-inductive digunakan dalam pendekatan kualitatif sehingga peneliti berusaha memahami sebuah gejala dari perspektif teori atau konsep tertentu (Hamad, 2005, hlm. 6). Dalam riset ini, peneliti berusaha memahami strukturasi komunikasi internal di dalam sistem departemen public relations.

Penelitian ini menggunakan metode studi kasus instrumental tunggal yaitu studi kasus interaksi dalam praktik media relations yang dilakukan oleh PR Trans TV. Hamad mengemukakan bahwa kata kunci dalam metode studi kasus adalah mengeksplorasi sebuah proses sehingga dapat memperlihatkan keterkaitan yang terdapat dalam sebuah atau beberapa kasus berdasarkan perspektif teoritis tertentu (2005, hlm. 7). Riset ini menggunakan satu kasus dari sebuah organisasi, yaitu Departemen Marketing Public Relations Trans TV dan berusaha memunculkan pola-pola atau konsep-konsep praktek komunikasi yang digunakan oleh agen di dalam organisasi ketika berinteraksi dengan struktur yang tengah berlaku pada saat penyusunan maupun pelaksanaan aktivitas media relations. Kemudian, dari riset ini dapat diperoleh gambaran proses produksi dan reproduksi struktur yang terjadi. Sifat dari penelitian ini adalah deskriptif karena berusaha untuk menjelaskan bagaimana sesuatu dapat terjadi dibandingkan menggali isu baru atau menjelaskan mengapa sesuatu terjadi.

Level penelitian ini terletak pada tataran organisasi karena berusaha menggambarkan sebuah organisasi pada level makro terkait kebijakan-kebijakandanstruktur(aturanatau norma) dalam sistem serta pada level mikro untuk menjelaskan tindakan-tindakan atau praktik-praktik komunikasi yang dilakukan oleh agen dengan struktur yang ada. Patton (2002, hlm. 228) menyebutkan bahwa unit analisis dapat berupa orang, kelompok, organisasi, peristiwa, dan program. Dalam penelitian ini, praktik media relations antar perusahaan media adalah unit analisis. Sedangkan unit observasi dari penelitian ini adalah agen atau individu. Unit observasinya adalah para staf media relations, supervisor media relations, dan kepala departemen dari Departemen Marketing Public Relations Trans TV sebagai narasumber utama dengan unit analisisnya berupa tindakan dalam kegiatan-kegiatan yang dilakukan dalam praktik media relations dan deskripsi interaksi dan relasi yang terjalin dengan pihak media.

Teknik penentuan informan dilakukan melalui purposive sampling, yaitu memilih key informants yang dianggap benar-benar memahami persoalan dalam penelitian ini karena key informants mengetahui 
atau memiliki pengetahuan khusus mengenai setting dari penelitian dan dapat menceritakan pengetahuan mereka tersebut sehingga dapat membantu peneliti dalam memahami apa yang terjadi dan mengapa hal tersebut bisa terjadi (Patton, 2002, hlm. 321). Teknik pengumpulan data dilakukan dengan wawancara mendalam (depth interview) kepada 3 narasumber berdasarkan teknik snowball. Patton (2002, hlm. 237) menyatakan bahwa pendekatan snowball sampling dilakukan untuk menemukan informan yang menjadi kunci dalam suatu kasus sehingga direkomendasikan untuk mendapatkan narasumber sebanyak mungkin. Narasumber dalam penelitian ini meliputi: (1) Kepala Departemen Marketing PRTrans TV; (2) Supervisor of Media Relations Trans TV; dan (3) Staf media relations. Data primer sebagai data utama dalam riset ini adalah hasil wawancara kepada 3 narasumber tersebut.

\section{HASIL DAN PEMBAHASAN}

\section{Sistem, Praktik, dan Struktur}

Strukturasi merupakan produksi dan reproduksi sistem-sistem sosial melalui penggunaan aturan-aturan (rules) dan sumber daya-sumber daya (resources) para anggota dalam interaksi. Teori strukturasi menjelaskan bagaimana sistem sosial seperti organisasi diproduksi dan direproduksi melalui proses strukturasi yang sedang berlangsung di mana ada produksi, reproduksi, dan transformasi institusi sosial yang diwujudkan melalui pengunaan aturan oleh individu-individu (Yates \& Orlikowski, 1992, hlm. 188). Dalam adaptive structuration theory, para anggota kelompok kerja mengadaptasi aturan dan sumber daya untuk mencapai tujuan mereka (Griffin, 2006, hlm. 238). Melalui strukturasi, dapat diperoleh gambaran mengenai proses struktur sosial yang membentuk tindakan orang-orang sementara itu pada saat bersamaan struktur sosial juga dibentuk oleh tindakan mereka. Dengan kata lain, proses ini disebut dualitas struktur, yang meliputi tindakan produksi dan reproduksi. Teori ini berguna bagi komunikasi karena berfokus pada interaksi sebagai arena di mana proses strukturasi terjadi dan berguna untuk memahami komunikasi sebagai sebuah proses (McPhee \& Poole, 2005, hlm. 180). Strukturasi komunikasi internal menggambarkan proses

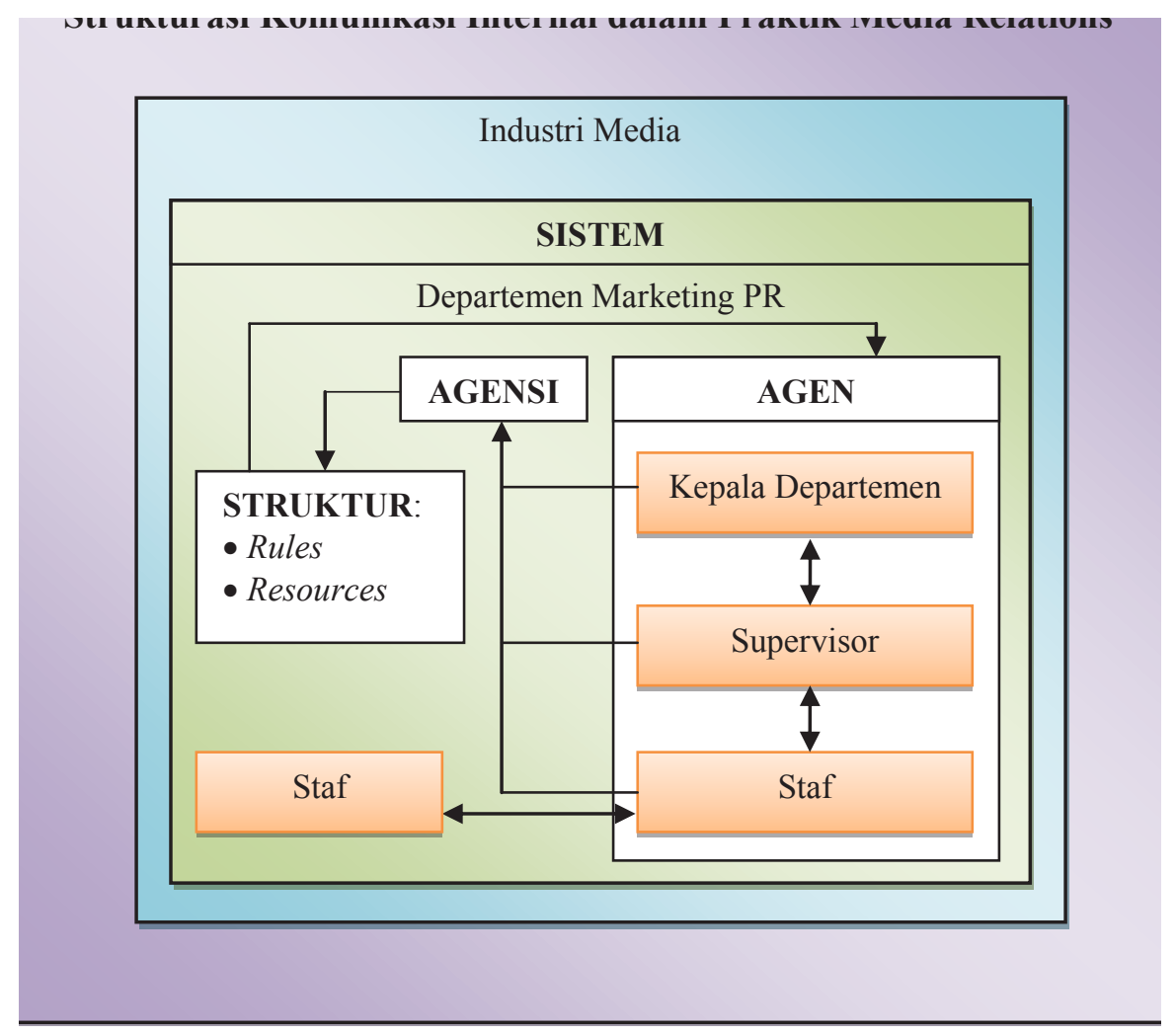

Figur 1. Strukturasi Komunikasi Internal dalam Praktik Media Relations 
produksi dan reproduksi sistem komunikasi di dalam satu departemen, yaitu Departemen Marketing PR Trans TV, terkait praktik media relations melalui penggunaan rules dan resources para agen dalam interaksi. Proses strukturasi dapat digambarkan dalam figur 1.

Trans TV merupakan salah satu industri media yang melakukan praktik media relations. Sebagai industri media, Trans TV menggunakan kreativitas para karyawannya sebagai resource (sumber daya). Menurut Küng, kreativitas adalah resource strategis yang sangat penting bagi media (2008, hlm. 145). Trans TV dapat dikatakan sebagai industri kreatif karena menggunakan strategi advertising, marketing, dan public relations dalam aktivitasnya (Küng, 2008, p. 7). Aktivitas public relations di Trans TV dapat ditemukan dalam Departemen Marketing Public Relations (PR). Salah satu dari aktivitas PR yaitu media relations. Aktivitas komunikasi internal dalam media relations mencakup proses komunikasi di dalam Departemen Marketing PR Trans TV yang melibatkan Kepala Departemen Marketing PR, Supervisor Media Relations, dan staf Media Relations. Dengan kata lain, para agen yang terlibat dalam praktik media relations yaitu (1) staf media relations, (2) supervisor media relations, dan (3) kepala departemen. Sistem komunikasi internal para agen dapat terlihat dari pola hubungan: (1) antara staf media relations dengan atasannya (supervisor dan kepala departemen) dan (2) antara staf media relations dengan staf unitunit lain.

\section{Komunikasi Internal}

Ketika para agen bertindak dan interaksi untuk memproduksi dan mereproduksi sistem di dalam lingkungan organisasi, mereka melakukan tindakan komunikasi, yaitu komunikasi internal. Komunikasi internal dalam praktik media relations dapat dipahami melalui penelusuran pola jaringan komunikasi di dalam satu departemen. Jaringan komunikasi internal ini terlihat dari saluran aliran pesan formal yang berdasarkan struktur hirarki dalam departemen yang secara struktural terjadi dalam jaringan komunikasi formal. Papa et al. menyebutkan bahwa jaringan komunikasi formal sebagai komunikasi yang dilakukan melalui saluran aliran pesan formal yang didesain dan terjadi di antara posisi-posisi dalam organisasi (2008, hlm. 51). Di dalam komunikasi internal antara staf media relations dengan atasannya, terdapat sistem komunikasi downward, komunikasi upward, dan komunikasi diagonal. Sedangkan komunikasi antara staf media relations dengan staf unit-unit lain merupakan sistem komunikasi horizontal.

Komunikasi downward merupakan komunikasi yang terjadi dari atasan kepada bawahannya. Goldhaber menyatakan bahwa komunikasi downward merupakan komunikasi atasan ke bawahan, pesan-pesan mengenai tugas dan pemeliharaan terkait dengan arahan, tujuan, disiplin, perintah, pertanyaan dan kebijakan (1993, hlm. 155). Komunikasi ini dalam praktik pembuatan press release terjadi ketika kepala departemen memberi persetujuan press release yang akan dipublikasikan. Komunikasi ini dapat dilakukan secara langsung dengan lisan atau melalui telepon dan dengan tulisan melalui e-mail. Komunikasi ini terkait dengan instruksi pekerjaan, yaitu arahan bagaimana atau seperti apa press release yang layak dipublikasikan dan pemberian acc untuk mempublikasikan press release.

Komunikasi upward merupakan komunikasi yang terjadi dari bawahan ke atasan. Komunikasi upward melibatkan transmisi pesan dari tingkat yang lebih bawah ke tingkat yang lebih tinggi dalam organisasi (Papa et al., 2008, hlm. 53). Dalam sistem Departemen Marketing PR Trans TV, komunikasi dari bawahan ke atasan terjadi ketika staf media relations meminta acc draft press release, mengajukan usulan dalam meeting internal, dan menyampaikan laporan kerja dan progress proyek. Komunikasi ini dilakukan secara secara langsung dengan lisan dan dengan tulisan melalui e-mail atau dalam lembar laporan. Dalam hal ini, komunikasi upward ini berguna dalam pembuatan keputusan (decision-making) ketikamemintapersetujuandraftpressrelease 
dan mengajukan usulan dalam meeting; dalam pemecahan masalah (problem solving) ketika mengajukan usulan dalam meeting; dan dalam pengembangan kebijakan dan prosedur ketika menyampaikan laporan kerja dan progress proyek.

Komunikasi horisontal terjadi di antara anggota organisasi dari divisi/departemen/ unit/sub-unit yang berbeda dengan posisi hirarki yang setara dalam suatu organisasi. Komunikasi horisontal meliputi aliran pesan yang terjadi antar area fungsional pada level tertentu dalam organisasi (Papa et al., 2008, hlm. 55). Komunikasi horizontal (antar staf) terjadi ketika staf media relations meminta masukan berupa usulan dan bantuan dalam mempersiapkan event. Komunikasi ini dilakukan secara langsung dengan lisan dan dengan tulisan. Ketika mempersiapkan press conference, staf media relations meminta bantuan bagian publicity terkait desain backdrop, bagian merchandising terkait souvenir, dll.

Komunikasi diagonal merupakan komunikasi yang terjadi antara staf suatu departemen dengan kepala departemen dari departemen yang lain. Komunikasi diagonal merupakan komunikasi yang terjadi antar tingkat kedudukan dan fungsi atau departemen dalam organisasi (Papa, et al., 2008, hlm. 57). Komunikasi diagonal (bawahan dan atasan dari departemen yang berbeda) terjadi ketika staf media relations meminta persetujuan menggali informasi kepada kepala departemen lain. Misalnya untuk menggali informasi tentang suatu program acara baru, staf media relations meminta izin kepada kepala departemen produksi dengan sepengetahuan dari kepala departemen marketing PR atau supervisor media relations. Komunikasi ini dilakukan secara tulisan melalui memo. Komunikasi diagonal ini dilakukan untuk berkoordinasi dan konfirmasi dalam menggali informasi suatu program atau kasus.

Sistem komunikasi internal dapat terlihat dalam praktik media relations yang meliputi aktivitas: (1) pembuatan press release, (2) monitoring pemberitaan, dan (3) pengajuan usulan. Ketika membuat press release, staf media relations mulamula membuat draftnya terlebih dahulu dan terkadang supervisor media relations mendampingi secara langsung dalam perangkaian informasi. Setelah mendapat persetujuan dari supervisor media relations, maka staf media relations meminta persetujuan dan pengesahan kepada kepala departemen. Dengan adanya paraf kepala departemen dalam press release tersebut, staf media relations bisa mempublikasikannya ke publik, khususnya ke pihak redaksi industri media lain. Monitoring pemberitaan merupakan aktivitas rutin yang berpola dan yang dilakukan staf media relations setiap harinya. Aktivitas ini dilakukan untuk mengetahui jumlah dan konten pemberitaan Trans TV yang telah dimuat oleh industri media lain sehingga dapat digunakan sebagai acuan evaluasi kinerja staf dan mengetahui reputasi Trans TV yang dibentuk oleh media lain. Untuk artikel berita yang dimuat di media cetak, staf media relations setiap pagi membaca beberapa koran dan mengumpulkan artikelartikel yang memuat berita mengenai Trans TV dan program-program tayangannya. Untuk artikel berita yang dimuat di media online, staf media relations mencari artikel berita mengenai Trans TV melalui mesin pencari di Internet dan terkadang ada jurnalis yang mengirimkan link atau tautan berita yang ditulis dan dipublikasinya melalui saluran industri media di mana dia bekerja. Improvisasi dapat terlihat dalam aktivitas pengajuan usulan dilakukan ketika diadakannya meeting internal departemen marketing PR di mana para staf, para supervisor, dan kepala departemen berkumpul bersama. Staf media relations dapat mengajukan usul diadakannya suatu event beserta budget atau anggaran yang dibutuhkan untuk mengadakannya. Pengajuan usul ini merupakan sarana supaya sistem dan praktik yang ada di dalam departemen marketing PR tetap berjalan dinamis dan para staf dapat menyalurkan kreativitas mereka. Terkait operasional pemberian usulan, staf media relations dapat mengajukan usulan diadakannya suatu 
event dengan dan meminta persetujuan dari kepala departemen hingga ke kepala direksi karena menyangkut budget yang diperlukan untuk melaksanakannya dan pengajuan tersebut dilakukan melalui memo. Untuk operasional persiapan event, staf media relations berhubungan langsung dengan staf-staf lain dari berbagai sub-unit di dalam departemen marketing PR. Dalam meeting internal di mana semua para anggota departemen marketing PR berkumpul, staf media media relations melakukan koordinasi dengan staf-staf lain dalam mempersiapkan event, seperti press conference, media award, media gathering, dll. Koordinasi tersebut terwujud ketika staf media relations menanyakan mengenai desain backdrop kepada staf publicity, souvenir kepada staf merchandising, dll.

Struktur adalah aturan-aturan (rules) dan sumber daya (resources) yang dibawa oleh aktor-aktor yang terlibat dalam praktik sistem (McPhee \& Poole, 2005, hlm. 174). Sebuah aturan (rule) adalah prinsip atau rutinitas yang memandu orang dalam bertindak. Sedangkan sebuah sumber daya (resource) adalah segala sesuatu yang orang gunakan dalam bertindak, baik itu materi (uang, peralatan) maupun nonmateri (pengetahuan, skill). Struktur digunakan oleh para agen dalam proses produksi dan reproduksi praktik dan sistem. Dalam menjalankan praktik media relations, para agen menggunakan rules: (1) prosedur, (2) kebijakan, dan (3) job description dan resources: (1) pengalaman, (2) kepercayaan, (3) kreativitas, (4) pengetahuan, dan (5) kemampuan/skills. Penggunaan rules dan resources tersebut dapat ditemukan dalam interaksi: (1) antara staf media relations dengan kepala departemen ketika mereview dan meng-acc artikel press release; dan mengajukan usulan event dan budget, (2) antara staf media relations dengan supervisor ketika meminta acc draft press release dan menyampaikan laporan kerja harian dan progres proyek, dan (3) antara staf media relations dengan staf unit-unit lain ketika meminta masukan dan bantuan mempersiapkan event.
Para agen, yaitu kepala departemen, supervisor dan staf media relations, menggunakan rules dan resources untuk memproduksi dan mereproduksi sistem komunikasi internal tersebut. Rules yang digunakan adalah (1) prosedur, (2) kebijakan, dan (3) job description. Prosedur yang dimaksudkan adalah prosedur publikasi press release dan prosedur penggalian informasi sebagai bahan release. Kebijakan mengacu pada kebijakan penggunaan press release dan pengadaan press conference. Job description yang digunakan Kepala Departemen Marketing PR dalam melakukan agensi dalam lingkungan internal adalah: (1) menyusun dan menetapkan Planning, Strategi, dan Konsep seluruh kegiatan Departemen Marketing Public Relations, (2) menganalisa, mengawasi dan mengevaluasi secara langsung pelaksanaan kegiatan setiap bagian dalam Departemen Marketing Public Relations, (3) mengkoordinasikan dan mengkomunikasikan tugas di lingkup Marketing Public Relations Departemen dengan pihak terkait di dalam lingkungan TRANSTV, dan (5)meningkatkankomunikasi internal perusahaan. Sementara itu job description untuk supervisor media relations ketika bertindak dan berinteraksi dalam lingkungan internal Trans TV meliputi: (1) menganalisa, mengawasi dan mengevaluasi secara langsung pelaksanaan kegiatan setiap bagian di lingkup Media Relations agar berjalan dengan baik, (2) membuat laporan setiap pelaksanaan kegiatan dibawahnya untuk disampaikan kepada Marketing Public Relations Departement Head, (3) meningkatkan komunikasi internal perusahaan. Sedangkan dalam reproduksi dan reproduksi struktur dan sistem, staf media relations memiliki job description seperti: (1) membuat, menyusun dan mengusulkan Planning, Strategi, dan Konsep kegiatan Media Relations, (2) melaksanakan dan mengkoordinasikan pekerjaan Media Relations dengan pihak terkait di dalam lingkungan TRANS TV, dan (3) membuat laporan berkala atas pelaksanaan setiap kegiatan Media relations untuk disampaikan kepada Supervisor Media Relations dan Kepala Departemen Marketing PR. 
Sementara itu, resourcesyang digunakan adalah (1) pengalaman, (2) kepercayaan, (3) kreativitas, (4) pengetahuan, dan (5) kemampuan/skills. Pengalaman yang dimaksudkanadalah pengalaman melakukan aktivitas sebagai staf media relations, seperti menjalin relasi dengan jurnalis, membuat press release, dll. Anggaran merupakan sumber daya yang penting karena tanpa adanya anggaran atau budget maka staf media relations tidak dapat mengadakan eventevent dan memberikan apresiasi kepada para jurnalis. Aktivitas-aktivitas yang dilakukan oleh staf media relations tidak dapat berjalan dengan baik jika tidak mendapat kepercayaan dari atasannya, karenanya staf media relations diberi kepercayaan dalam mengembangkan relasi dengan redaksi industri media lain sebanyak dan seluas mungkin serta membuat dan menyusun informasi dalam press release. Karena Trans TV merupakan industri media yang mengandalkan kreativitas sebagai sumber daya, makaparastafPRpundiberi kesempatan dalam mengembangkan dan menyalurkan kreativitasnya dalam memberikan ide dan saran dalam pengadaan suatu event atau aktivitas lainnya. Pengetahuan merupakan sumber daya yang diperoleh ketika para anggota departemen marketing PR menempuh pendidikan di universitas atau ketika bekerja atau magang, sehingga dari pengetahuan ini membuat mereka tahu apa yang harus dilakukan sebagai seorang public relations (PR) dalam praktik media relations. Sedangkan untuk kemampuan/ skill, para anggota departemen marketing PR setidaknya bisa mengoperasikan komputer dan menggunakan Internet, karena misalnya staf media relations mencari berita online, staf tersebut harus bisa mengoperasikan komputer dan menggunakan Internet dan mencari berita terkait Trans TV menggunakan mesin pencari.

\section{Dualitas Struktur: Produksi dan Reproduksi}

Proses produksi dan reproduksi merupakan dualitas struktur. Produksi dapat berupa tindakan transformasi, yaitu produksi sistem kearah yang berbeda sehingga dengan perubahan tersebut reproduksi sistem tetap dapat berlangsung (McPhee \& Poole, 2005, hlm. 175). Produksi (perubahan atau transformasi) praktik di lingkungan internal departemen meliputi (1) inovasi penggunaan teknologi komunikasidan (2)aliran informasi internal dalam pembuatan dan publikasi press release yang dinamis. Perubahan yang berupa inovasi dalam penggunaan teknologi komunikasi dapat terlihat dari adanya media sosial, web, dan aplikasi smartphone yang semua itu membutuhkan koneksi Internet. Departemen marketing PR Trans TV sedang mengembangkan penggunaan saluran media untuk menyebarkan informasi dalam internal departemen dan antar departemen Trans TV. Diharapkan dengan perkembangan dari media konvensional ke media online atau digital, pertukaran informasi lebih mudah, lebih cepat tersampaikan dan lebih akurat. Selain itu aliran informasi internal dalam pembuatan dan publikasi press release pun turut berubah. Apabila dalam situasi yang mendesakatau urgent dan kepala departemen tidak berada di tempat ketika staf media relatios hendak meminta persetujuan, maka staf media relation dapat menggunakan e-mail untuk mengirimkan draft press release kepada kepala departemen dan nantinya press release tersebut dimintakan tanda tangan oleh supervisor media relations atas sepengetahuan dan persetujuan kepala departemen. Jika ada press release tersebut mengenai Trans TV pada tingkat korporasi, maka staf media relations pun harus meminta acc atau persetujuan dari direksi yang bersangkutan.

Ketika aturan dan sumber daya digunakan untuk bertindak dalam sebuah sistem praktik sosial, kita menjaga sistem tersebut tetap berjalan atau kita memproduksi kembali (reproduce) sistem dan strukturnya (McPhee dan Poole, 2005, hlm. 175). Reproduksi (rutinitas) di lingkungan internal departemen marketing PR Trans TV meliputi: (1) meeting rutin internal departemen dan (2) monitoring pemberitaan. Meeting rutin internal dapat meliputi meeting mingguan, bulanan dan 
tahunan. Dalam meeting mingguan, para staf menyampaikan laporan kerja harian selama seminggu kepada atasannya dan melakukan koordinasi kerja untuk seminggu ke depan. Sedangkan dalam meeting bulanan, para staf menerima evaluasi kerja dari atasan mereka dan dalam meeting tahunan, semua anggota departemen marketing PR berkumpul untuk mendiskusikan rancangan kerja departemen marketing PR selama setahun ke depan dan para staf dapat menyampaikan ide dan saran tentang aktivitas-aktivitas setahun ke depan. Dari hasil meeting tahunan ini, para staf mendapatkan daftar pekerjaan yang harus dilakukan setiap hari, setiap minggu dan setiap bulannya. Monitoring pemberitaan merupakan tugas rutin harian dari staf media relations. Staf media relations setiap pagi membaca koran yang diterbitkan oleh industri media lain dan mencari berita mengenai Trans TV yang kemudian dibuat klipingnya. Sedangkan untuk media online, monitoring dilakukan dengan cara mencari artikel-artikel berita mengenai Trans TV melalui mesin pencari di Internet dan menelusuri link atau tautan berita yang dikirimkan oleh para jurnalis.

\section{SIMPULAN}

Trans TV sebagai organisasi yang bergerak dalam industri media membutuhkan kreativitas sebagai sumber dayanya. Kreativitas tersebut dapat terlihat dengan adanya aktivitas public relations yang dapat ditemui di Departemen Marketing Public Relations (PR) Trans TV. Salah satu dari aktivitas public relations tersebut adalah media relations. Praktik media relations meliputi aktivitas: (1) pembuatan press release, (2) monitoring pemberitaan, dan (3) pengajuan usulan. Departemen Marketing PR merupakan sebuah sistem. Sebagai sebuah sistem, di dalam lingkungan internal (di dalam departemen), para anggota dari Departemen Marketing PR Trans TV, yang terdiri atas staf, supervisor, dan kepala departemen, saling berhubungan. Ketika para agen bertindak dan interaksi untuk memproduksi dan mereproduksi sistem di dalam lingkungan organisasi, mereka melakukan tindakan komunikasi, yaitu komunikasi internal. Di dalam komunikasi internal antara staf media relations dan atasannya, terdapat sistem komunikasi downward, komunikasi upward, dan komunikasi diagonal. Sedangkan komunikasi antara staf media relations dengan staf unit-unit lain merupakan sistem komunikasi horizontal.

Untuk menjaga keberlangsungan sistem dan praktik diperlukan struktur. Struktur terdiri atas aturan dan sumber daya. Stuktur di dalam departemen marketing PR Trans TV adalahaturan berupa (1) prosedur, (2) kebijakan, (3) kode etik dan (4) job description. Sealin itu, terdapat pula sumber daya yang digunakan dalam bertindak oleh para anggota Departemen Marketing Public Relations yang meliputi (1) pengalaman, (2) anggaran, (3) kepercayaan, (4) kreativitas, (5) pengetahuan, dan (6) kemampuan/skill. Dualitas struktur terjadi dalam proses produksi dan reproduksi. Proses produksi membuat praktik media relation mengalami transformasi dan menjadi dinamis dengan adanya perubahan. Proses produksi dapat ditemukan dengan dengan adanya inovasi penggunaan teknologi komunikasi dan aliran informasi internal dalam pembuatan dan publikasi press release yang dinamis. Sedangkan proses reproduksi membuat praktik media relations menjadi sebuah rutinitas atau berjalan tanpa ada perubahan. Proses reproduksi dapat diketahui dengan adanya meeting rutin di dalam internal departemen dan monitoring pemberitaan. Di dalam sistem terdapat interaksi antara staf media relations dan para atasannya. Interaksi antara staf media relations dengan kepala departemen terjadi ketika membuat undangan press conference, me-review artikel berita, mengajukan usulan event dan budget, permintaan acc draft press release. Interaksi antara staf dengan supervisor terlihat ketika meminta acc draft press release, dan menyampaikan laporan kerja harian dan progress proyek. Sedangkan interaksi antara staf media relations dengan staf-staf unit lain nampak ketika staf media relations meminta masukan dan bantuan dalam mempersiapkan event. Oleh karena itu, dengan penggunaan struktur tersebut, para agen dapat memproduksi dan mereproduksi sistem komunikasi internal dalam sebuah organisasi melalui interaksi dalam praktik media relations. 


\section{DAFTAR PUSTAKA}

Albarran, Alan B. (1996). Media Economics: Understanding Markets, Industries and Concepts. Ames: Iowa State University.

Andjani, Made Dwi. (2009). "Media Relations sebagai Upaya Pembentuk Reputasi Organisasi”, Sultan Agung Vol XLV No.119.

Argenti, Paul A. (2003). Corporate Communication, zed. New York: McGraw-Hill Companies, Inc.

Denzin, Norman K and Lincoln, Yvonna S.. (1994). Handbook of Qualitative Research. Thousand Oak: Sage Publication.

Fadillah, Dani. (2017). Pola Komunikasi Internal Brajamusti Menjelang Pilkada Kotamadya Yogyakarta 2017. Jurnal INFORMASI Vol. 47, nomor 1 (halaman 121-133)

Giddens, Anthony. (2010). Teori Strukturasi: Dasar-Dasar Pembentukan Struktur Sosial Masyarakat. Diterjemahkan oleh Maufur \& Daryatno dari The Constitution of Society: Outline of the Theory of Structuration. Yogyakarta: Pustaka Pelajar.

Goldhaber, Gerald M. (1993). Organizational Communication $6^{\text {th }}$ Edition. New York: McGraw-Hill.

Griffin, Em. (2006). A First Look at Communication Theory $7^{\text {th }}$ Edition. Boston: McGraw-Hill. www.afirstlook. com

Hamad, Ibu. (2006). "Bagaimana Mempercayai Hasil Penelitian?”. Jurnal Thesis, September-Desember 2006. Universitas Indonesia.

Iriantara, Yosal. (2005). Media Relations: Konsep, Pendekatan dan Praktik. Bandung: Simbiosa Rekatama Media.

Johnston, Jane. (2013). Media Relations: Issues $\mathcal{E}$ Strategies $2^{\text {nd }}$ Edition. Sydney: Allen \& Unwin
Küng, Lucy. (2008) Strategic Management in the Media. London: SAGE Publications Ltd.

Littlejohn, Stephen W. dan Foss, Karen, A.. (2009). Encyclopedia of Communication Theory. Thousand Oaks: SAGE Publications, Inc.

McPhee, R D. (1989). "Organizational Communication: Structural Exemplar". Dalam Dervin, B., Grossberg, L., O’Keefe, B., \& Wartella, E. (Eds.). Rethinking Communication: Paradigm Exemplars. California: Sage Publications, Inc.

McPhee, Robert D. dan Poole, Marshall Scott. (2005). "Structuration Theory". Dalam Steve May dan Dennis K. Mumby. Engaging Organizational Communication Theory \& Research: Multiple Prespectives. Thousand Oaks, California: Sage Publications, Inc.

Mumby, Dennis K. dan Stohl, Cynthia. (1996). Disciplining Organizational Communication Studies. Sage Publications, Inc. Journal of Management Communication Quarterly, Vol. 10, No. 1, Agustus 1996 (halaman 50-72)

Pang, Augustine. (2010). "Mediating the media: a journalist-centric media relations model." Corporate Communications: An International Journal Vol. 15 No.2 2010 (hlm.192-204). Emeral Group Publishing Limited.

Papa, J. M., Daniels, T. D. \& Spiker, B. K. (2008). Organizational Communication Perspectives and Trends. California: Sage Publications, Inc.

Patton, Michael Quinn. (2002). Qualitatif Research $\mathcal{E}$ Evaluation Methods. Thousand Oaks, California: Sage Publications.

Putnam, Linda. (1983). Communication and Organizations: An Interpretive Approach.California:SagePublications, Inc. 
Theaker, Alison. (2004). The Public Relations Handbook, Second Edition. New York: Routledge.

Yates, Joanne dan Orlikowski, Wanda J.. (1992). Genres of Organizational: A Structurational Approach to Studying Communication and Media. The Academy of Management Review, Vol 17, Issue 2. (halaman 299-326). 